\title{
1 Comparing politics of quality in education
}

\author{
Jaakko Kauko, Tuomas Takala, and Risto Rinne
}

\section{Introduction}

This book is about understanding the politics of quality in education. Understanding this politics is our goal because the question of quality has become one of the most important framing factors in education policy and practice. It has been of growing interest to international organisations and national policies since at least the 1990s (Leeuw 2002; Power 1994; Smith 1990). We are interested in how the emphasis on quality has changed the basic conditions in which education takes place.

Before it is operationally defined, "quality in education" remains abstract and elusive. Like "choice" or "standards", it may have rhetorical appeal as a generally desirable idea, but it is not until it is put into practice, or "operationalised", that it becomes definable (Kauko et al. 2016; Dahler-Larsen 2015). The same is true for the evaluation of quality. There is little consensus currently even among evaluators as to what constitutes sound evaluation, with some adopting nearly opposite methodological and theoretical stances. (Dahler-Larsen 2012; Grek et al. 2009; Karlsson Vestman \& Segerholm 2009).

Our research seeks to investigate how quality is operationalised and the repercussions this has for the room for action for the different actors involved in education. By actors, we mean the teachers, students, parents, politicians, and civil servants and the organisations they represent who have different room for action, from the local to the global.

We focus on what we call quality assurance and evaluation, QAE (see Ozga et al. 2011). "Quality assurance" implies the need to demonstrate quality (of education) to outsiders (Harvey 2004-17); "evaluation" refers to the general aim of learning and changing current practices, providing "retrospective assessment of public-sector interventions, their organisation, content, implementation and outputs or outcomes, which is intended to play a role in future practical situations" (Vedung 2010). Our definition of QAE is intentionally wide, and it encompasses an array of activities used to evaluate and assure quality, such as student assessment and testing, programme and policy evaluation, school personnel and institutional evaluation, accreditation, curriculum evaluation, selfevaluation, inspection, and auditing (Kellaghan, Stufflebeam, \& Wingate 2003). 
The most common instance of QAE under scrutiny in this book is represented by national large-scale assessments of student achievement.

The importance of understanding QAE is that it is a tool to exercise power (Dahler-Larsen 2015: pp. 29-31), regardless of whether we take a classical view of power as related to resources, attributes, and formal positions (Mills 1956; Dahl 1961; see Bachrach \& Baratz 1962; Lukes 1974) or see it as more relational and structural (e.g., Foucault 2003; Heiskala 2001). Indeed, QAE is a governance tool, which means that procedures intended to enhance quality in education with the help of evaluation are used to achieve political aims, and they shape the power situation of the actors involved.

If one accepts our definition of QAE as a tool of power, it is no surprise that QAE has been embraced in policymaking. For example, international organisations and national governments are greatly optimistic in their use of QAE as a tool of governance. In the field of comparative education, there is vast and growing research into the international and transnational formation of education policy agendas and their influence on policymaking in individual countries (e.g., Chabbott 2002; Mundy 2007; Steiner-Khamsi and Waldow 2012; Verger, Novelli, \& Altinyelken 2012). The concepts of the international and the transnational are even sometimes used interchangeably, but by the former, we mean the actions which happen between national actors or with the help of international organisations, while by the latter, we mean the unofficial and official networks of action and ideas which exist without a restrictive relationship with national borders. Much of the literature mentioned focuses on how international organisations may guide or condition national education policy decisions. They do this by framing policy discussions and providing related technical advice and by prioritising the promise of external funding for projects and sector programmes (e.g., Beech 2006; King 1991).

Rational planning with the help of QAE contrasts with the long tradition of research literature claiming that policymaking never has the grassroots result politicians expect. Studies of the policy process (e.g., Jenkins-Smith \& Sabatier 1993; Baumgartner \& Jones 2009) have pointed out the institutional limitations created by history (Pierson 2000) or norms (March \& Olsen 1989) and drawn on chaotic-sounding notions, such as organised anarchy or "garbage can" (Cohen, March, \& Olsen 1972; Kingdon 2003). In education, there are also many generalising analyses of how reforms fail (e.g., Ball 2001). As Tyack and Cuban (1995) note, it is important to understand how schools act to change intended reforms.

This book is a result of the research project "Transnational Dynamics of Quality Assurance and Evaluation Policies in Brazil, China, and Russia", funded by the Academy of Finland between 2014 and 2017 (grant numbers 307310, 273871, 274218, 273874). During these four years, we conducted 200 interviews with 278 people from different levels of action, conducted observations, and analysed documents. The work was undertaken in three sub-projects, which were responsible for data collection in each country. Crucially, researchers were fluent in the respective national languages of our case countries. 


\section{Our ontological assumptions}

The challenge of policy planning is linked to the book's ontological assumptions the complexity and contingency of the world. We understand them as coherent and overlapping descriptions of the same thing from the perspectives of complexity theory (complexity) and social sciences (contingency). Complexity theories share ideas of systemic behaviour through the interaction of its parts (e.g., emergence and positive and negative feedback), non-linear causation (e.g., partial determination, probabilistic event progression), and different kinds of branching effects (e.g., path dependencies, irreversibility, or punctuated equilibria) (Wimmer 2006; Cairney \& Geyer 2015; Kauko 2014; Room 2015; Biesta \& Osberg 2010). In the social sciences, contingency means that change trajectories are possible but not necessary (Joas 2004; Medd 2002; see Kauko \& Wermke 2018). Politics is thus essentially the organisation and reorganisation of contingency (Kauko 2014; Palonen 1993, 2003, 2006): it is a game in which the basic conditions and constraints for action are defined.

QAE is a good example of the attempt to take political control of complexity. These attempts to channel and control contingency take different shapes. Classically, in political science and complexity theory, a basic limitation is presented by institutions and their formation:

Institutions constrain and channel agent interactions; however, they can also be subverted from below or reformed from above, as actors lift their gaze, reflect upon the overall socio-economic system in which they live and reinforce or reshape the rules and architectures of those systems. This is the stuff of politics and political choice... It accepts the potential value of modelling social dynamics as a self-organizing system, analogous to those in the natural sciences. On the other hand, it insists that social science must also be centrally interested in the socio-political processes by which these dynamics are re-shaped.

(Room 2015: p. 20)

We attempt to build an understanding of these socio-political processes and their enabling or restriction of the dynamics possible in the discussed setting. This also requires an understanding of history in observing path dependencies (Capano 2009). They indicate how past solutions create a dynamic of increasing returns (Pierson 2000) in which the costs of reversal due to institutional reorganisations grow continually (Levi 1997). These events in history shape the room for political action.

In short, our premises seek to understand the contingent and almost fragile context of political action and how it is always tied to longer-term sociohistorical developments, constrained or enabled by institutional rearrangements, and how actors are both entangled in and empowered by the dynamics which develop in these conditions. 
We have discussed how the ideas of complexity and contingency provide a good basis for not expecting an ideal of a conscious implementation process and have also questioned the ease with which QAE can be used as a governance tool. So, how is it possible to study this phenomenon?

\section{Unpacking policy transfer}

In terms of disciplinary traditions and boundaries, our book could be placed in the fields of comparative education, political science, or even international relations. In some cases, there may be more variance within a discipline than between disciplines. However, our main discussion is largely concerned with the field of comparative education, which influences our discussion across disciplines.

We agree with Rappleye (2012), who argues for a complex understanding of policy transfer and that in a globalising world, the question is crucial. He critically examines the prominent debate which circulates around a large body of system theories like the borrowing and lending theories, which especially analyse the influence of globalisation from the local perspective, and world culture theories, which see convergence in the structures of education systems globally (Rappleye 2012). Borrowing and lending theories study policy diffusion (Steiner-Khamsi 2004: p. 213), ranging from cross-cultural attraction to policy tourism (Steiner-Khamsi 2012). The leading idea of world culture theory is that educational systems around the world are developing in a similar direction structurally mainly as a result of communication amongst international organisations as they diffuse policy blueprints (Meyer, Boli, Thomas \& Ramirez 1997; Ramirez 2012). Disagreement between these views relates to the epistemological understanding of change (Kauko \& Wermke 2018) and the degrees of local and global influence (Rappleye 2012). According to Rappleye (2012: p. 49), the entrenched debate between these two perspectives has led to a "theoretical and conceptual fatigue".

Our research is interested in the effects of what is generally called policy transfer, but we would like to be more specific concerning the causality this implies for these traditions. Waldow (2012) sums up borrowing and lending theories as sharing the ideas of standardisation and legitimation. Standardisation refers to intentional and unintentional movement in a common direction and production of legitimacy to how external references are used to make internal changes or how policies are borrowed from a reference society. World culture theories do not, at least explicitly, consider reference societies but instead look at how nations influenced by world culture start consensually changing their systems towards a common structure (Meyer \& Ramirez 2003). Put simply, in both cases, diffusion bears the idea of a policy moving from one place to another, connoting three things: there must be a "source" (a reference society, international organisation, or "world culture"), there needs to be a recipient, and there needs to be an observable policy (or a "blueprint").

Our premise differs from these usual views of policy transfer. The analytical framework we endorse in this book leads to a disagreement with the notion 
of policy transfer, which in our view cannot cope with a sufficient degree of complexity for a thorough analysis of the process. Instead of discussing questions regarding source and target, global and local, and convergence and divergence, we believe that source and recipient become blurred in networks and flows and understanding the effects of policy transfer, embedded as it is in complex causation, requires theoretical tools to deal with contingencies, path dependencies, and probabilities. Ideas like these have been recognised, for example, under the label of post-structuralist theories (e.g., Larsen \& Beech 2014; Carney 2009) or when Schriewer (2003: p. 20) seeks to understand the "complexity of causal networks".

In analysing interactions between actors, we arrive at an understanding of dynamics as contingent. In the context of policy transfer, complex causation refocuses our analysis from the attempt to understand a policy's source, recipient, and enactment to an attempt to understand the web of factors which exist in a socio-historical situation and sustain a certain dynamic of change. We argue that central questions for analysing quality in education globally are 1) how quality is connected to transnational flows of knowledge and 2) how it offers a powerful governance tool for shaping education for several actors, including for some we would not usually consider.

\section{The transnational agenda of QAE}

Given our starting points, QAE in education offers a fruitful point for analysis, because it brings to the fore the theoretical aspects in which we are interested. QAE is a gateway to understanding transnational flows, because international and national actors use it as a tool of governance: measurement in education facilitates the creation of categories for the performance of individuals or organisations and for making decisions (Fenwick, Mangez, \& Ozga 2014).

The increased role of knowledge and data management in the making of education policy has been analysed as a recent development in the modes of governance (Carvalho 2013; Fenwick, Mangez, \& Ozga 2014; Lawn \& Segerholm 2011). As part of this change policy, advice has increasingly conveyed messages of "international best practice". Organisations such as the World Bank and the Organisation for Economic Cooperation and Development (OECD) have had an important role in the dissemination of these policies. These international organisations can be characterised as "epistemic communities" drawing on the knowledge dependency created by the increasing requirements for decisionmakers to deal with a broader range of issues in the expanding global economy and the consequent need for external advice (Armingeon \& Beyeler 2004; Haas 1992; Hasenclever, Mayer, \& Rittberger 2002; Kallo 2009: p. 357).

Our analysis of QAE is restricted to general school education (i.e., it excludes vocational and tertiary education). The transnational agenda around QAE is constructed within a network of actors which have no clear boundaries or identifiable centre of power or thought from which the agenda emanates. The network shares a common belief in the necessity of measuring learning outcomes as a key precondition for improving education quality worldwide 
(e.g., UNESCO Institute of Statistics 2013: pp. 14-16; World Bank 2013: p. 4; Center for Global Development 2013). Actors within the network consist of a wide range of multilateral organisations, for example, the World Bank; the OECD; the United Nations Educational, Scientific and Cultural Organisation (UNESCO); regional networks, such as the Latin American Laboratory for the Assessment of Quality in Education (LLECE) and the Southern African Consortium for the Measurement of Education Quality (SACMEQ); private professional bodies (the Brookings Institute, Educational Testing Services); academic experts; and consultants.

The policies of the three principal education-related international organisations relevant to QAE - the World Bank, UNESCO, and the OECD - vary in how their assistance is tied to money flows and the extent to which national and local actors are able to set the agenda. Whereas the World Bank is perceived as leaning towards a harder policy line, with leverage provided by its lending operations, the OECD has authority without financial clout, and UNESCO has been reduced to a relatively weak policy actor (Henry et al. 2001: pp. 17-18; Rinne \& Ozga 2011). While these organisations have different agendas, especially the World Bank and the OECD, and to an extent UNESCO, they share a similar toolkit: "a range of instruments that can be targeted at national policies: they can promote, develop and disseminate policies, coordinate, set standards, supply technical assistance and offer financial inducements" (Rinne \& Ozga 2013: p. 98).

The improvement of education quality can of course be justified by reference to any objective set for the education system. In contrast, the typical justification expressed for the transnational assessment agenda is notably narrow and even monotonous: reference is made in numerous sources to the finding that cognitive learning achievement - rather than years of schooling per se - has a positive impact on economic growth (original research paper by Hanushek \& Woessmann 2007; references, e.g., World Bank 2011: p. 24; Center for Global Development 2013: pp. 3-4). The corollary is that a well-functioning system of assessing learning outcomes is "a key driver of economic growth and poverty reduction” (READ 2010: p. 36).

The "problematisation" and overall policy advice on QAE in general school education found in the global World Bank documents in the past two decades illustrates the substance of the transnational agenda:

1) The principal goal of education is seen as contributing to economic growth and poverty reduction.

2) This contribution is crucially dependent on the quality of education.

3) There is mounting evidence from international assessments that the quality of education is low in many countries.

4) Information on learning achievement is needed both for monitoring education quality as a basis for policy decisions and for increased accountability of schools towards parents, communities, and donor agencies; such information should then provide incentives for improving quality.

5) The case is then made for the establishment of national assessment systems and wider participation in international assessments and related capacity 
building; to these, the World Bank and other agencies should provide support (World Bank 1995: pp. 1-3, 9, 15; 1999: pp. iii, vii-ix; 2005: pp. 12, 67-69; 2011: pp. 6-8).

The role of the OECD derives from its knowledge-production capacity. It is thought to have a central role in the flow of international educational ideas and in the governance of education (Rinne \& Ozga 2011), and the market-liberal ideological undercurrents in knowledge-making have also been noted (Dale 1999: pp. 1-4; Dale \& Robertson 2002: p. 11). The OECD's central role in setting international benchmarks makes it a broker of the main currency in the global education setting, which national policymakers usually see as a global competition (Lauder et al. 2006: p. 41; Robertson, Bonal Dale. 2002; Rinne, Kallo \& Hokka. 2004; Rinne \& Ozga 2011). The OECD's annual compendium, "Education at a Glance", has become a statistical "doxa", just as the PISA survey (Programme for International Student Assessment) and its indicators, rankings, and league tables are often taken as objective indicators which point the way to the improvement of results and placings in rankings in national educational policy (Rinne et al. 2004; Rinne \& Ozga 2011). Initially confined to OECD member countries, the PISA programme has been gradually expanded to non-member countries - including Brazil, China, and Russia - which share a history of having been clients of the World Bank. For such countries, this represents a significant symbolic upgrading of their international status.

The research on global agendas in education is nuanced and complex and deals with many of the basic problematics in the comparative education field (Verger, Novelli, \& Altinyelken 2012), which tend to emphasise the importance of international and transnational changes and their reshaping of the role of the state (Werner \& Zimmermann 2006; Robertson, Bonal, \& Dale 2002). Structurally, research seems to indicate the state's diminishing role as an education actor in the face of globalisation. The state is, on one hand, riddled with transnational influences, while, on the other, the global QAE agenda allows less independence. Where action is concerned, the content of the transnational QAE agenda seems to ignore the political undercurrents of QAE - the negotiations, interpretations, and difficulties highlighted in the above-mentioned research tradition concerning policymaking and governance. Using our analytical framework, we would expect to find more contingency and room for action in how transnational QAE data are used. We also analyse Russia and China, in which the state is heavily involved, thus critically examining the discussion of the state's diminishing importance.

\section{Comparing dynamics in education politics in Brazil, China, and Russia}

The case countries in our research are Brazil, China, and Russia. Their historical trajectories are described in more detail in Chapter 3. Here it is sufficient to mention that they present a clear set of common features which justify their selection for a comparative study. The term BRICS, coined in the new 
millennium (O'Neill 2001; Hurrel 2006) and applied to these three "emerging economies", along with India and South Africa, has been adopted by the case countries themselves, suggesting their global ambitions are somewhat similar. Brazil, China, and Russia aspire to regional leadership and leverage their economic and political positions through social policies, including education. Like other countries, they have increasingly focused on QAE in education (Chin 2012; Hurrel 2006; Lima 2012; Piattoeva \& Takala 2014; Rowlands 2012). In these three contexts, we analyse how QAE works in transnational networks, how data circulate, how QAE functions as a governance tool, and how all this affects the room for action available to different actors.

The terms "framework", "theory", and "model" are sometimes used interchangeably, but we follow Elinor Ostrom (2005: pp. 27-28), who understands them as nested. With the help of a framework, it is possible to loosely identify the essential elements for analysis: "They attempt to identify the universal elements that any relevant theory would need to include ... [E]lements contained in a framework help the analyst generate the questions that need to be addressed when first conducting an analysis" (Ostrom 2005: p. 28). Theory helps to focus the view further in making more specific assumptions:"a scholar needs to select one or more theories to use in generating predictions about expected patterns of relationships" (Ostrom 2005: p. 28). Models make more precise assumptions concerning a theory's sub-section. However, this is beyond the focus of our research. To understand QAE in education in the transnational context, we start our analysis with an analytical framework called Comparative Analytics of Dynamics in Education Politics (CADEP) (see Kauko et al. 2015; Simola et al. 2017). This idea is further refined with compatible theories in the subsequent chapters.

Using CADEP, we hope to tease out comparable and related patterns of action. Our framework's first word, "comparative", indicates that we analyse homologies between the different contexts. The second word, "analytics", indicates that we are interested in understanding actors' room for action. By focusing on "dynamics in education politics", we stress the importance of analysing the actual movement of the education system rather than focusing on actors' attributes. We thus shed light on the limits and possibilities for action on different levels. Simola et al. (2017) describe the dynamics in education politics as follows:

In many cases it [dynamics in education] is a result of contingencies in history, and is currently sustained by political action on different levels or that is constantly subjected to transnational flows. The action itself, regardless of whether or not it is considered political, derives from societal thought structures, is questioned or unquestioned, happens in the course of time, is connected to resources and past events, passes, and creates room for future action. What is called equality, trust, or progress is manifested through action, described here in terms of relational and contingent dynamics.

(Simola et al. 2017) 
To sum up, in attempting to grasp the multifaceted nature of both QAE and transnational flows, we share many of the ontological and epistemological premises of complexity theories. We emphasise the contingent nature of the world, the fact that events and change are possible but not necessary. Described in more detail in the next chapter, the three dimensions of the CADEP framework are derived from a vast conceptual-historical project (Palonen 2003, 2006) and analysis of the policy process (Kingdon 2003; Baumgartner \& Jones 2009; Sabatier \& Jenkins-Smith 1993).

- Political situation relates to the changing political constellations of actors associated with education quality and their effect on what is structurally possible on different scales of action.

- Analysis of political possibilities happens through the dominant discourses: what the relevant actors consider possible or what they consider to be the problem.

- The third dimension is the use of the political space. It relates to how the actors use the room for action created by the first two dimensions.

With the help of these three dimensions, our aim is to analyse how QAE as a transnational flow and governance tool changes the role of state, expertise, and governance and the room for action which exists for politicians, teachers, and other actors in varying contexts.

\section{The structure of the book}

Chapter 2 discusses the theoretical and analytical premises of our research and aims to increase its validity through methodological transparency. It draws on the idea of reflective research and discusses the questions of case selection and comparability, as well as the concrete work of data collection and analysis. Research journey narratives are used to consider field access and ethical issues and to produce another layer of research data about the manifestations of QAE. The chapter also reflects on the differences in data availability in the three countries and the limitations this poses for comparative analysis. To compare the dynamics which emerge in QAE policies in the different contexts, the chapter introduces the CADEP analytical framework in more depth and discusses the abductive research design, in which theoretical and empirical work are complementary.

Chapter 3 analyses the socio-historical background necessary for an understanding of the development of QAE policies in the three countries and for an analysis of the problematics in the following chapters. It outlines the historical paths of the development of QAE policies in each context during the postWorld War II period. First, it presents a case-by-case chronological account of these trajectories, based on document analysis and literature review; then it proceeds to a comparative analysis.

Chapter 4 is the first to use data from our fieldwork. Following the analytical framework, it analyses the changing national political arena in the Brazilian, 
Chinese, and Russian contexts. In this chapter, we ask how QAE has changed the roles of national and international actors in policymaking. We analyse interviews with representatives of international and national organisations and with individual actors and use document analysis as background material. We demonstrate that enhanced data infrastructure and expertise, along with other resources, have made national governments less dependent on international organisations, while remaining more interested in and interlinked with international trends.

Chapter 5 describes and analyses the changing roles of and relationship between the state and expertise in Brazil, China, and Russia. National policies aim to determine the development and application of QAE instruments as they empower state governance. However, the data generated are also strongly dependent on experts. In analysing interview data from experts, civil servants, politicians, and other stakeholders, we aim to discover who is considered a legitimate collector and analyst of QAE data. We find that a growing number of state-controlled systems allow experts some room for action but that state approval continues to serve as the main source of legitimation.

Chapter 6 discusses the concept of governance at a distance as a new form of governance in relation to the book's analytical framework. The expanding practices of QAE produce quantitative data about education which is said to allow the nation-state to extend its capacity to govern across territory and into the classroom. Governance at a distance relies on the production and circulation of data. This chapter focuses on the tensions and paradoxes which appear to make the process of governance at a distance through data less smooth than is generally depicted in both academic literature and political rhetoric. We first analyse official policy statements concerning where data are presumed to circulate and for what purpose. We then use interview data to explore the paradoxes emerging from the political objectives of data circulation and use and from the paradoxical nature of quantitative data about education itself.

Chapter 7 investigates the ways in which local authorities utilise QAE policies to govern schools and the effects this has on their room for action. The analysis draws on a combination of governance theories and on the political frame of organisational analysis. The fieldwork data were collected in selected localities in Brazil, China, and Russia by means of document analysis, interviews, and observations. We demonstrate that the QAE instruments are reinterpreted locally in accordance with the pre-existing practices of quality control and school governance and are biased towards local actors' political interests. Highperforming schools can thus utilise QAE policies to draw power from sources such as expertise, access to agenda setting, or building networks and coalitions, while low performers are increasingly disadvantaged. Schools' reputations act as a key to the virtuous or vicious cycles in which schools find themselves ensnared in the implementation of performance evaluation. Our findings also indicate that the room for action for those schools opposing new QAE policies is somewhat restricted. However, schools can practise hidden resistance and to a certain extent avoid the penetration of QAE tools into their internal processes. 
Chapter 8 analyses alternative futures of QAE as expressed by Brazilian, Chinese, and Russian actors. We use official policy documents and our interview data to investigate how national officials and experts see the future of QAE in their respective contexts and the trends they perceive as preferable or undesirable. Our findings are set against the backdrop of the case countries' socio-cultural history. We also compare the views expressed in interviews to a typology of future scenarios for societies and education. In addition to the envisioned "new" futures, we also find views of alternative futures which are rooted in domestic pedagogical traditions, including QAE practices, and express the desire to retain what the interviewees see as valuable in these traditions.

Chapter 9 draws together the main findings of our research and reflects on their theoretical significance. We conclude that there are three dynamics in the politics of quality in Brazil, China, and Russia. Self-reinforcing and shared goalsetting reflect how QAE has overtaken quality as a goal of education policy. Authorising but diverted governance describes how QAE enables a parallel trend of authorising more governance methods, while creating increasingly complex systems. Destabilising and reorganising role-setting indicates how the mechanisms of QAE create new actors in the field, which at the same time brings instability to the political system because of the potential of QAE data to provoke change.

\section{About our research and writing}

Many of the questions covered by this book have been dealt with extensively in the project's previously published or submitted articles. Reference to these is made in the chapters where relevant, and the respective bibliographical information is found in the chapters' reference lists.

The project consortium, led by Associate Professor Jaakko Kauko, consisted of three sub-projects, each responsible for investigating one of the case countries. The leaders of the sub-projects, who are also editors of this book, were Jaakko Kauko for the Brazil sub-project, Professor Risto Rinne for China, and Professor Tuomas Takala for Russia. The individual chapters' author teams worked in the sub-projects in varying roles (document analysis, interviews at different levels, fieldwork at the local level) and with varying total workloads. The researchers in the three sub-projects were

- Brazil: DrVera Gorodski Centeno, Dr Helena Hinke Dobrochinski Candido, Íris Santos

- China: Dr Johanna Kallo, Olli Suominen, Xingguo Zhou

- Russia: Dr Nelli Piattoeva, Galina Gurova, Anna Medvedeva

The project also benefited from valuable advice and support from three collaborating professors: Viktor Bolotov (Higher School of Economics, Moscow), Liu Min (Beijing Normal University), and Eneida Shiroma (Federal University of Santa Catarina). We also invited Professor Romuald Normand (University of Strasbourg) to contribute to one of the chapters. 
The project's work mode was a combination of the individual responsibilities first defined in the project plan and subsequently adjusted in the course of its implementation and frequent internal communication and intensive periodic workshops. Thus, the designation of individual members of the project teams as authors of chapters can only express the division of responsibilities in the writing process: it does not fully reflect all the individual contributions to the intellectual process of our data analysis which underpinned the writing of this book.

\section{Bibliography}

Adams, D. (1993). Defining Educational Quality (IEQ Publications No. 1). Pittsburgh: University of Pittsburgh.

Alasuutari, P. (2009). The domestication of worldwide policy models. Ethnologia Europaea, 39(1), 66-71.

Alvesson, M., \& Sköldberg, K. (2009). Reflexive Methodology: New Vistas for Qualitative Research (2nd ed.). London: Sage.

Anderson-Levitt, K. M. (2012). Complicating the concept of culture. Comparative Education, $48(4), 441-445$.

Armingeon, K., \& Beyeler, M. (Eds.). (2004). The OECD and European Welfare States. Northampton: Edward Elgar Publishing, Inc.Bachrach, P., \& Baratz, M. S. (1962). Two faces of power. The American Political Science Review, 56(4), 947-952.

Ball, S. J. (2001). Global policies and vernacular politics in education. Currículo Sem Fronteiras, 1(2), xxvii-xliii.

Ball, S. J. (2012). Global Education Inc.: New Policy Networks and the Neoliberal Imaginary. London \& New York, NY: Routledge.

Baumgartner, F. R., \& Jones, B. D. (2009). Agendas and Instability in American Politics (2nd ed.). Chicago, IL: Chicago University Press.

Beech, J. (2006). Redefining Educational Transfer: International Agencies and the (Re)production of Educational Ideas. In J. Sprogoe \& T. Winter-Jensen (Eds.), Identity, Education and Citizenship - Multiple Interrelations. Frankfurt am Main: Peter Lang.

Biesta, G., \& Osberg, D. (2010). Complexity, education and politics from the inside-out and the outside-in: An introduction. In D. Osberg \& G. Biesta (Eds.), Complexity Theory and the Politics of Education (pp. 1-4). Rotterdam: Sense Publishers.

Cairney, P., \& Geyer, R. (2015). Introduction. In R. Geyer \& P. Cairney (Eds.), Handbook on Complexity and Public Policy (pp. 1-15). Cheltenham: Edward Elgar Publishing.

Capano, G. (2009). Understanding policy change as an epistemological and theoretical problem. Journal of Comparative Policy Analysis: Research and Practice, 11(1), 7-31.

Carney, S. (2009). Negotiating policy in an age of globalization: Exploring educational "Policyscapes" in Denmark, Nepal, and China. Comparative Education Review, 53(1), 63-68.

Carvalho, L. M. (2013). The fabrications and travels of a knowledge-policy instrument. European Educational Research Journal, 11(2), 172-188.

Center for Global Development. (2013). Schooling Is Not Education! - Using Assessment to Change the Politics of Non-Learning. Retrieved December 21, 2017, from www.cgdev.org/ doc/full_text/CGDReports/3120290/schooling-is-not-education.html

Chabbott, C. (2002). Constructing Education for Development - International Organizations and Education for All. New York, NY: Routledge \& Falmer.

Chin, G. (2012). Two-way socialization: China, the World Bank, and Hegemonic weakening. Brown Journal of World Affairs, 19(1), 211-230.

Cohen, M. D., March, J. G., \& Olsen, J. P. (1972). A garbage can model of organizational choice. Administrative Science Quarterly, 17(1), 1-25. 
Dahl, R. A. (1961). Who Governs? New Haven: Yale University Press.

Dahler-Larsen, P. (2011). Afterword. In O. Jenny, D.-L. Peter, S. Christina, \& S. Hannu (Eds.), Fabricating Quality in Education: Data and Governance in Europe (pp. 151-159). London: Routledge.

Dahler-Larsen, P. (2012). Constitutive effects as a social accomplishment: A qualitative study of the political in testing. Educational Inquiry, 3(2), 171-186.

Dahler-Larsen, P. (2015). The evaluation society: Critique, contestability and skepticism. SpazioFilosofico, 1, 21-36.

Dale, R. (1999). Specifying globalization effects on national policy: a focus on the mechanisms. Journal of Education Policy, 14(1), 1-17.

Dale, R., \& Robertson, S. L. (2002). The varying effects of regional organizations as subjects of globalization of education. Comparative Education Review, 46(1), 10-36.

Fejes, A. (2006). The Bologna process - governing higher education in Europe through standardisation. Revista Española de Educación Comparada, 12, 203-231.

Fenwick, T., Mangez, E., \& Ozga, J. (2014). Governing Knowledge: Comparison, KnowledgeBased Technologies and Expertise in the Regulation of Education. London: Routledge.

Foucault, M. (2003). Society Must Be Defended: Lectures at the Collegge de France, 1975-1976. New York, NY: Picador.

Grek, S., Lawn, M., Lingard, B., \& Varjo, J. (2009). North by northwest: Quality assurance and evaluation processes in European education. Journal of Education Policy, 24(2), 121-133.

Grek, S., \& Rinne, R. (2011). Fabricating Europe. In J. Ozga, P. Dahler-Larsen, C. Segerholm, \& H. Simola (Eds.), Fabricating Quality in Education: Data and Governance in Europe (pp. 19-31). London: Routledge.

Haas, P. (1992). Introduction: Epistemic communities and international policy coordination. International Organisation, 46(1), 1-35.

Hanushek, E. A., \& Woessmann, L. (2007). The role of education quality for economic growth (Policy Research Working Paper No. 4122). Washington, DC: World Bank.

Harvey, L. (2004-2017). Analytic quality glossary. Quality Research International. Retrieved from www.qualityresearchinternational.com/glossary/

Hasenclever, A., Mayer, P., \& Rittberger, V. (2002). Theories of International Regimes (5th ed.). Cambridge Studies in International Relations 55. Cambridge: Cambridge University Press. Hedström, P., \& Wittrock, B. (2009). Introduction: Frontiers of sociology. In P. Hedström \& B. Wittrock (Eds.), Frontiers of Sociology (pp. 1-11). Leiden: Koninklijke Brill.

Heiskala, R. (2001). Theorizing power: Weber, Parsons, Foucault and neostructuralism. Social Science Information, 40(2), 241-264.

Held, D., McGrew, A., Goldblatt, D., \& Perraton, J. (1999). Global Transformations: Politics, Economics and Culture. Stanford: Stanford University Press.

Henry, M., Lingard, B., Rizvi, F., \& Taylor, S. (2001). The OECD, Globalization and Education Policy. Oxford: International Association of Universities.

Hurrel, A. (2006). Hegemony, liberalism and global order: What space for would-be great powers? International Affairs, 82(1), 1-19.

Jenkins-Smith, H. C., \& Sabatier, P. A. (1993). The study of public policy processes. In H. C. Jenkins-Smith \& P. A. Sabatier (Eds.), Policy Change and Learning: An Advocacy Coalition Approach (pp. 1-9). Boulder, CO: Westview Press.

Joas, H. (2004). Morality in an age of contingency. Acta Sociologica, 47(4), 392-399.

Kallo, J. (2009). OECD Education Policy. A Comparative and Historical Study Focusing on the Thematic Reviews of Tertiary Education. FERA: Jyväskylä.

Karlsson Vestman, O., \& Segerholm, C. (2009). Dialogue, deliberation and democracy in educational evaluation - theoretical arguments and a case narrative. In The SAGE Handbook of Educational Evaluation (pp. 465-482). London: Sage. 
Kauko, J. (2013). Dynamics in higher education politics: A theoretical model. Higher Education, 65(2), 193-206.

Kauko,J. (2014). Complexity in higher education politics: Bifurcations, choices and irreversibility. Studies in Higher Education, 39(9), 1683-1699.

Kauko, J., Centeno, V. G., Candido, H., Shiroma, E., \& Klutas, A. (2016). The emergence of quality assessment in Brazilian basic education. European Educational Research Journal, 15(5), 558-579.

Kauko,J., Corvalán, J., Simola, H., \& Carrasco, A. (2015). Historical dynamics in Chilean and Finnish basic education politics. In P. Seppänen, A. Carrasco, M. Kalalahti, R. Rinne, \& H. Simola (Eds.), Contrasting Dynamics in Education Politics of Extremes: School Choice in Chile and Finland (pp. 29-52). Rotterdam: Sense Publishers.

Kauko, J., \& Wermke, W. (2018). The contingent sense-making of contingency: Epistemologies of change in comparative education. Comparative Education Review 62(2).

Kellaghan, T., Stufflebeam, D., \& Wingate, L. (2003). Introduction. In T. Kellaghan \& D. Stufflebeam (Eds.), International Handbook of Educational Evaluation (pp. 1-6). Dordrecth: Kluwer Academic Publishers.

King, K. (1991). Aid and Education in the Developing World - the Role of the Donor Agencies in Educational Analysis. Harlow: Longman.

Kingdon, J. W. (2003). Agendas, Alternatives, and Public Policies (2nd ed.). New York, NY: Longman.

Larsen, M. A., \& Beech, J. (2014). Spatial theorizing in comparative and international education research. Comparative Education Review, 58(2), 191-214.

Lauder, H., Brown, P., Dillabough, J-A., \& Halsey, A. H. (Eds.). (2006). Education, Globalization E Social Change. Oxford: Oxford University Press.

Lawn, M., \& Segerholm, C. (2011). Europe through experts and technologies. In J. Ozga, P. Dahler-Larsen, C. Segerholm, \& H. Simola (Eds.), Fabricating Quality in Education: Data and Governance in Europe (pp. 32-46). London: Routledge.

Leeuw, F. L. (2002). Evaluation in Europe 2000: Challenges to a growth industry. Evaluation, $8(1), 5-12$.

Levi, M. (1997). A model, a method, and a map: Rational choice and historical analysis. In M. Lichbach \& A. Zuckerman (Eds.), Comparative Politics: Rationality, Culture and Structure (pp. 19-41). Cambridge: Cambridge University Press.

Lima, M. C. (2012). O Brasil, os BRICS e a agenda internacional [Brazil, BRICS and an international agenda]. FUNAG, 153-174.

Lukes, S. (1974). Power: A Radical View. London: Palgrave Macmillan.March, J. G., \& Olsen, J. P. (1989). Rediscovering Institutions: The Organizational Basis of Politics. New York, NY: Free Press.

Medd, W. 2002. Complexity and the social world. International Journal of Social Research Methodology, 5(1), 71-81.

Meyer, J. W., Boli, J., Thomas, G. M., \& Ramirez, F. O. (1997). World society and the nation-state. American Journal of Sociology, 103(1), 114-181.

Meyer, J. W., \& Ramirez, F. O. (2003). The world institutionalization of education. In J. Schriewer (Ed.), Discourse Formation in Comparative Education (pp. 111-132). Frankfurt am Main: Peter Lang.

Mills, C. W. (1956). The Power Elite. New York, NY \& Oxford: Oxford University Press.

Mundy, K. (2007). Global governance, educational change. Comparative Education, 43(3), 339-357.

Nóvoa, A., \& Yariv-Mashal, T. (2003). Comparative research in education: A mode of governance or a historical journey? Comparative Education, 39, 423-439. 
O’Neill, J. (2001). Building better global economic BRICs. Goldman Sachs Inc. Retrieved June 9, 2013, from www.goldmansachs.com/our-thinking/archive/archive-pdfs/buildbetter-brics.pdf

Ostrom, E. (2005). Understanding Institutional Diversity. Princeton, NJ: Princeton University Press.

Ozga, J., Dahler-Larsen, P., Segerholm, C., \& Simola, H. (2011). Introduction. In J. Ozga, P. Dahler-Larsen, C. Segerholm, \& H. Simola (Eds.), Fabricating Quality in Education: Data and Governance in Europe (pp. 1-8). London: Routledge.

Ozga, J., \& Jones, R. (2006). Travelling and embedded policy: The case of knowledge transfer. Journal of Education Policy, 21(1), 1-17.

Palonen, K. (1993). Introduction: From policy and polity to politicking and politicization. In K. Palonen \& T. Parvikko (Eds.), Reading the Political: Exploring the Margins of Politics (pp. 6-16). Helsinki: Finnish Political Science Association.

Palonen, K. (2003). Four times of politics: Policy, polity, politicking, and politicization. Alternatives, 28, 171-186.

Palonen, K. (2006). The Struggle With Time: A Conceptual History of "Politics" as an Activity. Hamburg: Verlag Münster.

Pereyra, M. A. (2008). Preface. In M. A. Pereyra (Eds.), Changing Knowledge and Education. Communities, Mobilities, and New Policies in Global Societies (pp. 5-17). Frankfurt am Main: Peter Lang.

Piattoeva, N., \& Takala, T. (2014). Russia as a returning donor - four roles in development assistance to education. Globalisation, Societies and Education, 13(3), 388-410.

Pierson, P. (2000). Increasing returns, path dependence, and the study of politics. The American Political Science Review, 94(2), 251-267.

Power, M. (1994). The Audit Explosion. London: Demos.

Qadir, A. (2014). Culture and history in the domestication of global trends of higher education in Pakistan. In P. Alasuutari \& A. Qadir (Eds.), National Policy-Making: Domestication of Global Trends (pp. 147-163). London: Routledge.

Ramirez, F. O. (2012). The world society perspective: Concepts, assumptions, and strategies. Comparative Education, 48(4), 423-439.

Rappleye, J. (2012). Educational Policy Transfer in an Era of Globalisation: Theory - History Comparison. Frankfurt am Main: Peter Lang.

Rautalin, M. (2014). The role of PISA publicity in forming national education policy: The case of Finnish curriculum reform. In P. Alasuutari \& A. Qadir (Eds.), National PolicyMaking: Domestication of Global Trends (pp. 95-110). London: Routledge.

READ. (2010). READ annual report 2009. Russia Education Aid for Development (READ) Trust Fund. Retrieved December 21,2017, http://siteresources.worldbank.org/ INTREAD/Resources/READ_AnnualReport_2009_web.pdf

Rinne, R., Kallo, J., \& Hokka, S. (2004). Too eager to comply - OECD education policies and the Finnish response. European Educational Research Journal, 3(2), 454-485.

Rinne, R., \& Ozga, J. (2011). Europe and the global: The role of the OECD in education politics. In O. Jenny, D.-L. Peter, S. Christina, \& S. Hannu (Eds.), Fabricating Quality in Education: Data and Governance in Europe (pp. 66-75, 151-159). London: Routledge.

Rinne, R., \& Ozga, J. (2013). The OECD and the global re-regulation of teacher's work knowledge-based regulation tools and teachers in Finland and England. In T. Seddon \& J. S. Levin (Eds.), Educators, Professionalism and Politics: Global Transitions, National Spaces and Professional Projects. World Yearbook of Education 2013. New York, NY: Routledge.

Robertson, S. L., Bonal, X., \& Dale, R. (2002). GATS and the education service industry: The politics of scale and global reterritorialization. Comparative Education Review, 46(4), 472-495. 
Room, G. (2015). Complexity, power and policy. In R. Geyer \& P. Cairney (Eds.), Handbook on Complexity and Public Policy (pp. 19-31). Cheltenham: Edward Elgar Publishing.

Rowlands, D. (2012). Individual BRICS or a collective bloc? Convergence and divergence amongst "Emerging Donor" nations. Cambridge Review of International Affairs, 25(4), 629-649.

Sabatier, P. A., \& Jenkins-Smith, H. C. (1993). The advocacy coalition framework: Assessment, revisions, and implications for scholars and practitioners. In P. A. Sabatier \& H. C. Jenkins-Smith (Eds.), Policy Change and Learning. An Advocacy Coalition Approach (pp. 211235). Boulder, CO: Westview Press.

Schriewer, J. (2003). Comparative education methodology in transition: Towards a science of complexity? In J. Schriewer (Ed.), Discourse Formation in Comparative Education (pp. 3-52). Frankfurt am Main: Peter Lang.

Simola, H., Kauko, J., Varjo, J., Kalalahti, M., \& Sahlström, F. (2017). Dynamics in Education Politics - Understanding and Explaining the Finnish Case. London: Routledge.

Simola, H., Rinne, R., Varjo, J., \& Kauko, J. (2013, January 16). The paradox of the education race: How to win the ranking game by sailing to headwind. Journal of Education Policy.

Smith, D. (1990). Assessment, technology and the quality revolution. In T. Schuler (Eds.), World Yearbook of Education 1990: Assessment and Evaluation (pp. 41-55). London: Kogan Page.

Steiner-Khamsi, G. (2004). Blazing a trail for policy theory and practice. In G. SteinerKhamsi (Ed.), The Global Politics of Educational Borrowing and Lending (pp. 201-220). New York, NY \& London: Teachers College, Columbia University.

Steiner-Khamsi, G. (2012). Understanding policy borrowing and lending: Building comparative policy studies. In G. Steiner-Khamsi \& F. Waldow (Eds.), Policy Borrowing and Lending in Education. World Yearbook of Education 2012 (pp. 1-17). London \& New York, NY: Routledge.

Steiner-Khamsi, G. (2014). Comparison and context: The interdisciplinary approach to the comparative study of education. Current Issues in Comparative Education, 16(2).

Steiner-Khamsi, G., \& Waldow, F. (Eds.). (2012). Policy Borrowing and Lending in Education. World Yearbook of Education 2012. London \& New York, NY: Routledge.

Stromquist, N. P. (2007). Qualidade de ensino e gênero nas políticas educacionais contemporâneas na América Latina. Educação e Pesquisa, 33(1).

Tyack, D., \& Cuban, L. (1995). Tinkering toward Utopia: A Century of Public School Reform. Cambridge, MA: Harvard University Press.

UNESCO Institute of Statistics and Center for Universal Education at Brookings Institute. (2013). Towards Universal Learning - Recommendations From the Learning Metrics Task Force. Retrieved December 21, 2017, from www.uis.unesco.org/Education/Documents/lmtfsummary-rpt-en.pdf

Vedung, E. (2010). Four waves of evaluation diffusion. Evaluation, 16(3), 263-377.

Verger, A., Novelli, M., \& Altinyelken, K. (2012). Global education policy and international development: An introductory framework. In A. Verger, M. Novelli, \& K. Altinyelken (Eds.), Global Education Policy and International Development: New Agendas, Issues and Policies. London: Continuum.

Waldow, F. (2012). Standardisation and legitimacy: Two central concepts in research on educational borrowing and lending. In G. Steiner-Khamsi \& F. Waldow (Eds.), Policy Borrowing and Lending in Education. World Yearbook of Education 2012 (pp. 411-427). London \& New York, NY: Routledge.

Walters, W., \& Haahr, J. H. (2005). Governing Europe: Discourse, Governmentality and European Integration. Abingdon: Routledge. 
Werner, M., \& Zimmermann, B. (2006). Beyond comparison: "Histoire Croisée" and the challenge of reflexivity. History and Theory, 45(1), 30-50.

Wimmer, A. (2006). Models, methodologies, and metaphors on the move. In A. Wimmer \& R. Kössler (Eds.), Understanding Change: Models, Methodologies, and Metaphors (pp. 1-36). Houndmills: Palgrave Macmillan.

World Bank. (1995). Priorities and Strategies for Education - a World Bank Review. Washington, DC: World Bank.

World Bank. (1999). Education Sector Strategy. Washington, DC: World Bank.

World Bank. (2005). Education Sector Update. Washington, DC: World Bank.

World Bank. (2011). Learning for All 2020 - World Bank Group Education Strategy. Washington, DC: World Bank.

World Bank. (2013). Developing Skills for Innovative Growth in the Russian Federation. Washington, DC: World Bank. 